\title{
The danger of high growth combined with a large non-cash working capital base - a descriptive analysis
}

\author{
W. Steyn*, W.D. Hamman \& E.v.d.M. Smit \\ Graduate School of Business, University of Stellenbosch, \\ PO Box 610, Bellville 7535, Republic of South Africa \\ bws1@maties.sun.ac.za
}

Received March 2002

\begin{abstract}
A high growth rate may not be the ultimate measure of a successful company. This article shows that growth at too high a rate, for a company with a high non-cash working capital component, may lead to financial difficulties.

While the income statement of a company is based on the accrual of income and expenses, the cash flow statement is based on the receipt and payment of cash. A company experiencing high sales growth, depending on the extent of its noncash working capital, will find that the cash flow from operating activities before the payment of dividends will not grow as quickly as the net profit after taxation. This is because the accrual part included in the net profit after taxation is also growing at a high rate. At such a growth rate, operating activities do not generate sufficient cash to sustain the day -to-day activities of the company.
\end{abstract}

*To whom all correspondence should be addressed.

\section{Introduction}

The magical phrase for many people when reading the announcement of a company's financial results remains something in the line of: ' $X$ Ltd had another exceptional year with another surge of growth. Turnover rose by $150 \%$ and net profit increased by $80 \%$ '. Cash flow is frequently ignored and its absence often does not even raise a question.

Both the income statement and the cash flow statement of a company provide useful information on the financial performance of the company. The net profit, after taxation, in the income statement and the cash flow from operating activities, before payment of dividends, in the cash flow statement have basically the same transactions as source. They, however, carry complementing information because of timing differences between the accrual of income and expenses and the cash receipts and payments thereof, as well as the inclusion of certain items in the net profit after taxation, which form part of the cash flow from investing activities rather than the cash flow from operating activities.

Users of financial statements have to analyse both these figures before concluding on the financial performance of the company. This may be a complex exercise, especially when the difference between the net profit after taxation and the cash flow from operating activities (before any payment of dividends) is large, and when furthermore the income statement measure shows a profit, while the cash flow measure is negative or substantially smaller than the income statement figure.

Such a scenario will be prevalent in companies that are growing quickly, because a growth in revenue usually coincides with an increase in non-cash working capital. When the company is expanding too quickly, too much of its cash resources are taken up by the increase in non-cash working capital, which inevitably leads to cash flow problems. Frequently the users of financial statements underestimate the value in the cash flow figures while focusing on high growth figures and 'healthy' profits.

When a company is growing at a high rate, it usually will lead to an increase in profits. However, depending on the type of company, it will also lead to an increase in inventories, trade receivables and trade payables. In order to carry the larger client base, inventory levels must grow and therefore trade payables will increase. If the company is selling on credit, the amount of trade receivables will also increase. The accrual part of net profit will therefore increase and the necessary cash to finance the increase in non-cash working capital is not available. Furthermore, the company also needs cash to finance the expansion of noncurrent assets. For many a company pursuing high growth, mismanagement of cash flow eventually leads to its downfall.

The company with the higher revenue growth rate, the lower net profit margin or the longer working capital cycle will be the one most exposed to the cash flow risk. Over time the trends in the net profit after taxation and the cash flow from operating activities before the payment of dividends can be plotted on a graph, with the two lines moving away from each other as the difference between the two increases. At some point, the cash created by the operating activities can no longer sustain the growth and the company will need additional finance. If market sentiment does not allow a rights issue at this point or the company does not have a cash strong holding company, the company will most probably either be liquidated or become part of a business combination (acquisition or merger). This article aims to test this hypothesis by examining companies that had both been growing at an exceptionally high rate as well as carrying an exceptionally large amount of non-cash working capital. 


\section{Literature review}

According to Generally Accepted Accounting Practice (AC 118 par .15,) 'the amount of cash flows arising from operating activities is a key indicator of the extent to which the operations of the enterprise have generated sufficient cash flows to repay loans, maintain the operating capability of the enterprise, pay dividends and make new investments without recourse to external sources of financing' (SAICA, 1996).

Although the success of a company will eventually depend on its capability to generate more cash inflow than cash outflow, Dechow (1994) found that over a shorter period, the cash flow information would not necessarily be a better indicator of success than the net profit after taxation. The reason is that transactions are recorded in the income statement according to the accrual basis of accounting, while being recorded in the cash flow statement only when there is a flow of cash. Cash flow figures will therefore be a much noisier indicator.

Par. 27 of AC 101 (SAICA, 1999) sets out the accrual basis of accounting: 'transactions and events are recognised when they occur (and not as cash or its equivalent is received or paid) and they are recorded in the accounting records and reported in the financial statements of the period to which they relate'.

It is imperative that a company must be able to honour its obligations in time. Hull (1990) acknowledges that profitable activities will not necessarily generate cash when needed. According to him the cash from operating activities will be influenced by a number of factors such as:

- the operating profit of the previous year plus depreciation;

- the growth in sales;

- changes in the gross profit margin and the proportion of sales to sales expenses, general expenses and administrative expenses;

- $\quad$ changes in the proportion of trade receivables, trade payables and inventories to sales as well as prepaid and accrued expenses;

- $\quad$ interest paid; and

- taxation paid.

According to Shroff (1998) the trend in cash flow from operating activities is a useful indicator of future performance. He is of the opinion that a warning signal is received when the net profit and the cash flow move in opposite directions over time, and do not reverse, in which case it will be necessary to analyse the situation in depth.

According to Hertenstein and McKinnon (1997), the cash flow from operating activities is the main cash producer. The cash flow from operating activities can therefore be expected to be positive in order for the company to generate sufficient cash to finance its day-to-day activities as well as the replacement of non-current assets and the payment of dividends to shareholders. In a growing company, it can be expected that the non-cash working capital accounts, namely trade receivables, trade payables and inventories will increase. Situations where a decrease in the non-cash working capital of a growing comp any leads to an increase in cash flow from operating activities must be analysed with care, because it can be a sign that management managed the non-cash working capital with the purpose to produce cash because of cash flow problems.

Foster and Ward (1997) argue that a company in financial difficulties experiences negative cash flow from operating activities which drains the company's cash resources and makes it difficult to obtain further finance. Less cash is available to invest in investing activities. About one year before bankruptcy, the cash flow from financing activities becomes negative, because more cash is used repaying loans than can be obtained from new loans. A year before bankruptcy the cash flow from all three components becomes negative. The company cannot survive for an extensive period with all the cash flow components negative - when the cash resources are diminished, the company is bankrupt.

Although a company may have exceptional growth and profit figures, it is not necessarily an indication of success. It needs to generate cash flow from its operating activities, not only to survive, but also to be successful. This cash flow is a result of many contributing factors like sales growth, the profit margin and the extent of non-cash working capital. On its own a high sales growth may be good for the company, or a low profit margin or a high non-cash working capital component may not be bad for the company. However, a combination of these factors may be lethal to the company. This can be confirmed by examining companies' performance empirically.

\section{Reconciliation between the net profit after taxation and the cash flow from operating activities before payment of dividends}

The difference between the net profit after taxation and the cash flow from operating activities before payment of dividends will originate in either the timing difference between the accrual and cash bases of accounting or in the inclusion of items in the net profit after taxation that form part of investing activities. Examples are the profit or loss on the sale of investments or non-current assets or items that are part of the net profit after taxation, which will never represent a cash flow, for example depreciation. The income statement figure and the cash flow figure can thus be reconciled as follows (all the items will not necessarily be found in every situation):

\section{Net profit after taxation}

+ Non-cash items:

Depreciation

Amortisation

+/- Items that reflect investment activities rather than operating activities:

Profit/loss from the sale of non-current assets

Impairment losses and reversals of impairment losses on non-current assets

Receipt of capitalisation-issues 
Fair value adjustments on investment property

+/- Cash flow effect of extraordinary items not included in net profit after taxation

- Capitalised borrowing costs not included in net profit after taxation

\section{+/-Accruals of an income nature}

Unrealised profits and losses on foreign exchange

Movement in provision for bad debts

Other provisions

Deferred taxa tion

Taxation in arrears or paid in advance

\section{+/- Current accruals:}

Change in trade receivables

Change in inventories

Change in trade payables

Other changes (e.g. prepaid/accrued expenses and income)

\section{= Cash flow from operating activities before payment of dividends.}

\section{Illustration of the effect of growth and non-cash working capital}

Different factors influence cash flow from operating activities. This influence can be illustrated by means of a simple example. Only three factors will be used in this exa mple, namely a high/low growth in sales, a high/low non-cash working capital in proportion to sales, and a high/low net profit margin. The example is based on two assumptions: firstly the difference between the net profit after taxation and the cash flow fom operating activities before payment of dividends arise only because of the change in non-cash working capital as well as depreciation. Secondly the value allocated to the factors do not change over the period examined.

The following values were allocated to the factors: (These values are the calculated second (low) and eighth (high) deciles of the actual database of listed industrial companies used (Table 2).)

- High growth: $26,8 \%$

- Low growth: $3,4 \%$

- High non-cash working capital* in proportion to sales: $27,4 \%$
- Low non-cash working capital* in proportion to sales: $5,4 \%$

- High net profit after taxation to sales: $8,7 \%$

- Low net profit after taxation to sales: $1,3 \%$

- Depreciation of $1 \%$ of sales is used throughout

* Non-cash working capital $=$ trade receivables + inventories - trade payables.

If the sales for Company X is R280 000000 in year 1, the cash flow from operating activities can be calculated for year 2 . From Table 1 can be seen that the company in the best cash flow position in year 2 (R30 387 000) will be the one with a high growth rate, a high net profit margin and a low non-cash working capital to sales ratio. The company in the worst position (-R12 395 000) is the one with a high growth rate, low net profit margin and a high non-cash working capital to sales ratio. Interesting enough, a high growth rate can be beneficial when the company does not have a high non-cash working capital ratio. However, when the company does have a high amount of non-cash working capital, it cannot afford to grow at too high a rate.

The company with a higher net profit ratio will always be in the more fortunate position, as the base from which cash is created is higher. However, if a company grows at a very high rate and carries a very high amount of non-cash working capital, even the high profit margin may not be sufficient to prevent cash flow problems.

These different scenarios can be illustrated over a five-year period. The graphs clearly demonstrate which company is the most likely to experience cash flow problems.

The ideal position for a company is when it can be growing at a high rate, have a low amount of non-cash working capital and its net profit ratio is high (Figure 1). The cash flow from operating activities will also grow at a high rate and this company ought to be successful.

However, it is not only companies with low non-cash working capital ratios that are chasing high growth. The danger for the high non-cash working capital ratio companies is that they tend to focus too much on expansion and thus growth in net profit, that cash flow is not always managed. The company will still be safe if it has a high net profit margin (Figure 2). However, if growth is exceptionally high or the non-cash working capital is of exceptional high levels, even a high profit will not be able to prevent cash flow problems.

Table 1: Calculation of cash flow from operating activities per scenario

\begin{tabular}{|c|c|c|c|c|c|c|}
\hline Year 2 & $\begin{array}{l}\text { Sales } \\
\text { R'000 }\end{array}$ & Net profi & taxation & Cash flo & $\begin{array}{l}\text { n operating a } \\
\text { R'000 }\end{array}$ & \\
\hline $\begin{array}{l}\text { High growth } \\
\text { Low growth }\end{array}$ & $\begin{array}{l}355040 \\
289520\end{array}$ & $\begin{array}{c}\text { High } \\
30888 \\
25188\end{array}$ & $\begin{array}{l}\text { Low } \\
4616 \\
3764\end{array}$ & $\begin{array}{l}\text { High non-cash } \\
\text { Low non-cash } \\
\text { High non-cash } \\
\text { Low non-cash }\end{array}$ & $\begin{array}{c}\text { High profit } \\
13878 \\
30387 \\
25475 \\
27569\end{array}$ & $\begin{array}{c}\text { Low profit } \\
-12395 \\
4114 \\
4050 \\
6145\end{array}$ \\
\hline
\end{tabular}




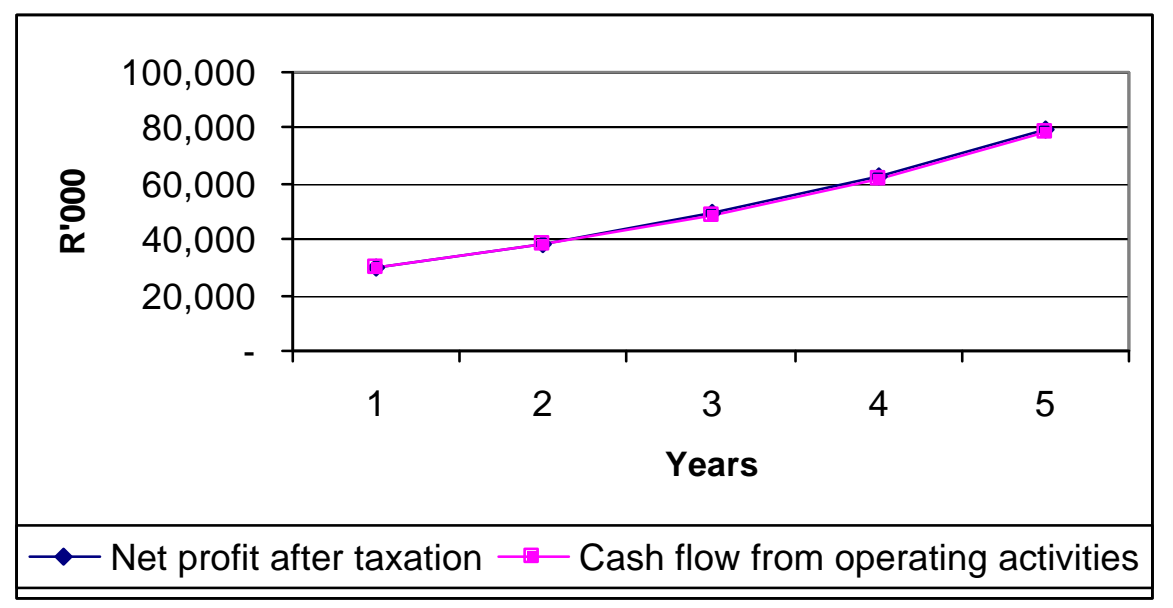

Figure 1: A high growth rate, low non-cash working capital and a high net profit ratio

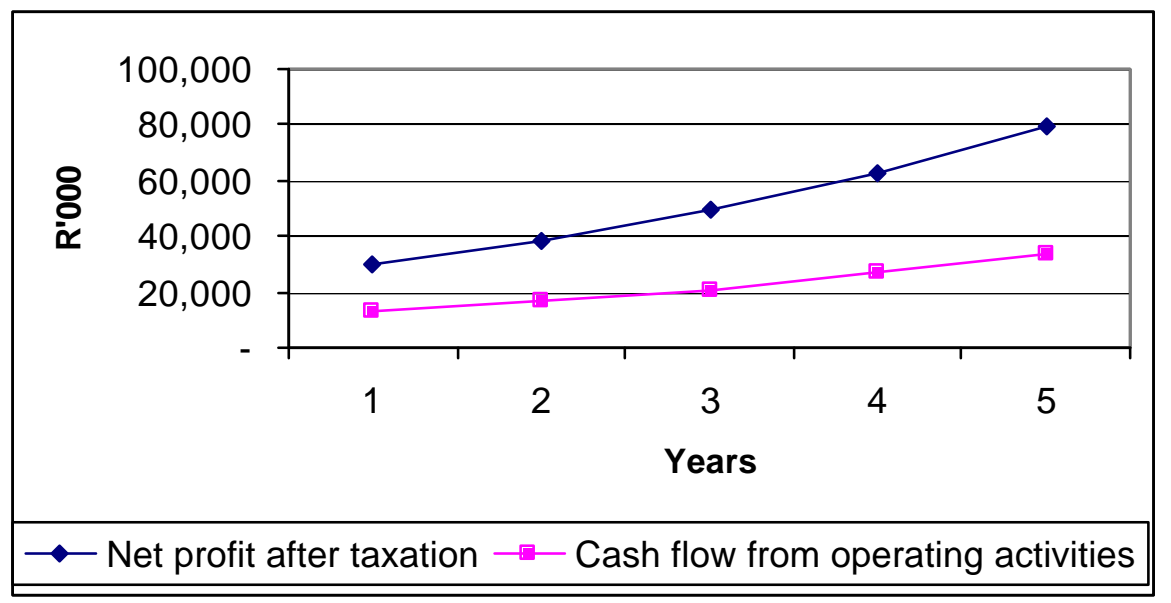

Figure 2: A high growth rate, high non-cash working capital and a high net profit ratio

A low profit margin will most probably see this company in cash flow difficulty (Figure 3). Because of a low profit margin, a high growth rate does not make a huge difference in the net profit. The non-cash working capital is however growing at that high rate and therefore causes the accrual part of the net profit to increase. That leads to an increasing negative cash flow from operating activities.

Growth, the non-cash working capital and cash flow ought to be managed. A company with a high non-cash working capital can rather grow slower and survive, than growing at too high a rate (Figure 4). The net profit will not be as phenomenal as when growing quickly, but the cash flow from operating activities is much better as the amount of non-cash working capital is not increasing at a high rate. This company will have a better chance for survival and not be growing itself into cash flow problems.

Management of these factors is a fine balance that needs to be reached in time. It is important to remember that the cash flow from operating activities illustrated in these scenarios did not take into account any dividends paid; any replacement of non-current assets; or any repayment of loans. In the short term a company may survive with a barely positive cash flow from operating activities, however, if this situation should continue, the company will most probably find itself in cash flow difficulty.

The company that is growing at a high rate, still has market sentiment on its side and will be able to do a rights issue; as well as the company with a cash rich holding company that is willing to keep on investing in the subsidiary, are both fortunate. However, the company that does not find itself in such favourable circumstances will either find itself a victim of a business combination or be in a position where it will be delisted, or at worst be liquidated.

\section{Research methodology}

The aim of this article is to examine companies that had been expanding at an exceptional high rate over a few years as well as carrying an above average amount of non-cash working capital over that same period. This is in order to conclude whether these companies could survive on their own and are still listed or whether they have been delisted or have become part of a business combination or have been forced to do a rights-issue. 


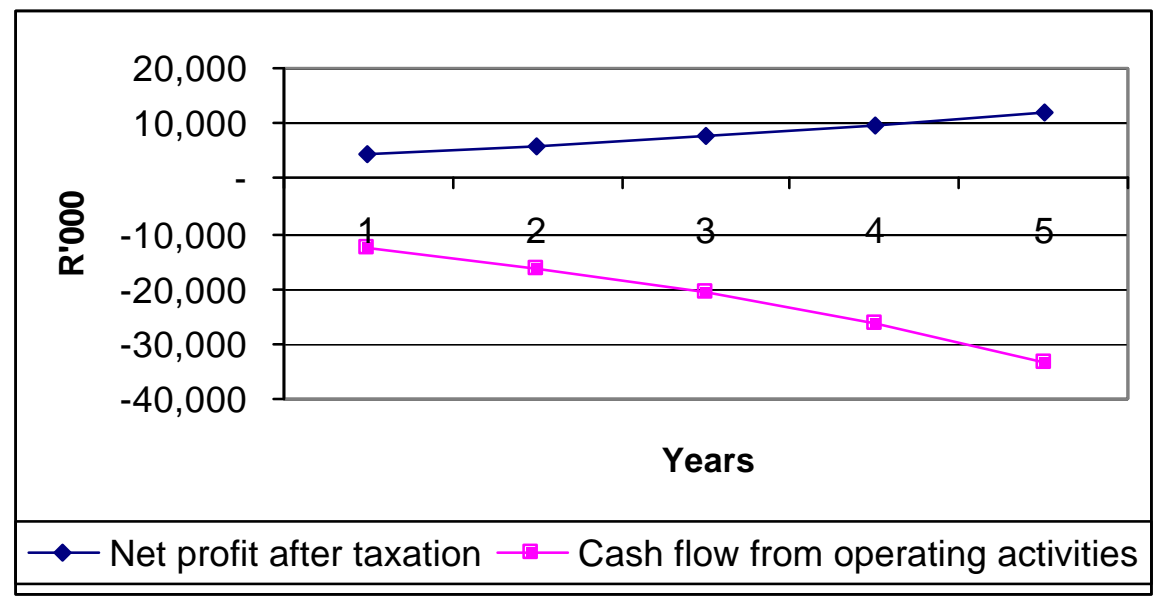

Figure 3: A high growth rate, high non-cash working capital and a low net profit ratio

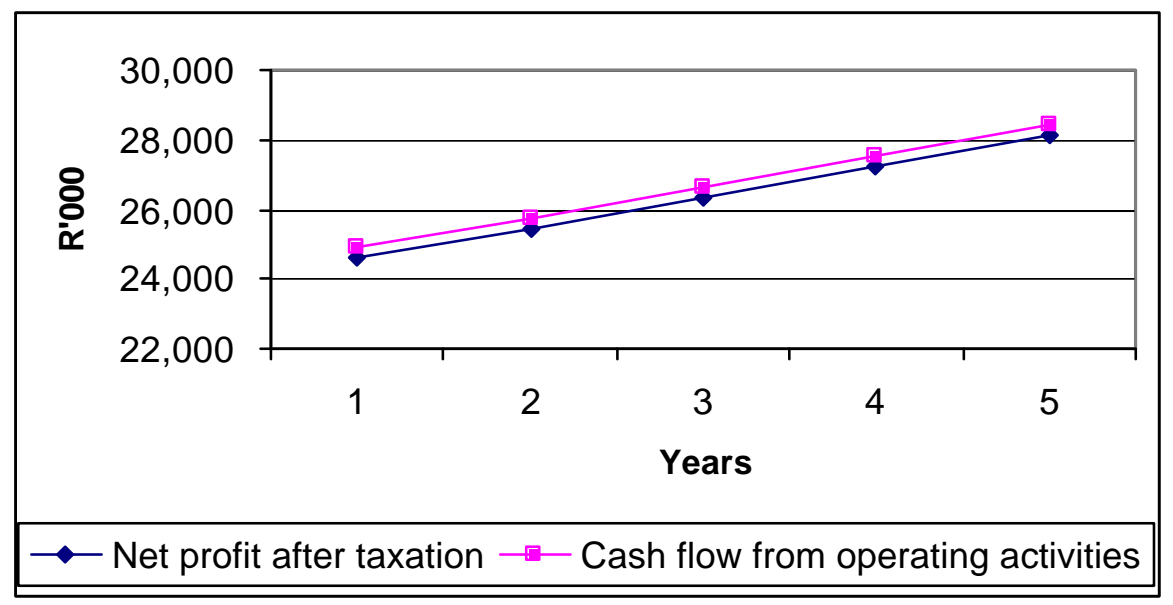

Figure 4: A low growth rate, high non-cash working capital and a high net profit ratio

It was decided to test this hypothesis on industrial companies listed on the JSE for at least five years. All the companies that were listed for at least five years during the period 1991 to 2000 , and that were not registered outside South Africa or Namibia, were used. That amounted to 269 companies.

For each of these companies the following ratios were calculated:

- $\quad$ an average growth ratio based on a yearly equivalent of sales;

- an average non-cash working capital ratio (trade receivables + inventories - trade payables to sales);
- an average of the net profit after taxation as a percentage of sales; and

- an average of the cash flow from operating activities before payment of dividends as a percentage of sales.

The ratios were calculated for the five-year period before and including the last year of listing or before a business combination or, for the companies still Isted in 2000, the five years before and including 2000.

Table 2: Descriptive statistics of the companies

\begin{tabular}{l|c|c|c|c}
\hline $\begin{array}{c}\text { Descriptive } \\
\text { statistics }\end{array}$ & Growth in sales & $\begin{array}{c}\text { Non-cash working } \\
\text { capital to sales }\end{array}$ & $\begin{array}{c}\text { Net profit after } \\
\text { taxation to sales }\end{array}$ & $\begin{array}{c}\text { Cash flow from operating } \\
\text { activities to sales }\end{array}$ \\
\hline Mean & $20,35 \%$ & $17,36 \%$ & $4,88 \%$ & $5,27 \%$ \\
Median & $12,03 \%$ & $14,23 \%$ & $4,30 \%$ & $4,89 \%$ \\
Second decile & $3,40 \%$ & $5,41 \%$ & $1,35 \%$ & $1,29 \%$ \\
Eighth decile & $26,77 \%$ & $27,47 \%$ & $8,70 \%$ & $10,02 \%$ \\
Minimum & $-27,26 \%$ & $-18,11 \%$ & $-189,31 \%$ & $-140,07 \%$ \\
Maximum & $467,41 \%$ & $126,10 \%$ & $75,11 \%$ & $68,55 \%$ \\
\hline
\end{tabular}


The companies were ranked according to the average growth in sales as well as the average non-cash working capital. Table 2 contains the descriptive statistics for the 269 companies. The eighth decile for growth in sales is $26,77 \%$ and the eighth decile for the non-cash working capital ratio equals $27,47 \%$, meaning that there is $27,47 \mathrm{c}$ of non-cash working capital at year-end for every one Rand of sales during the year.

\section{Results}

From the 54 companies in the top quintile for a high sales growth, 26 have either been delisted or been part of a business combination. From the 28 still listed, ten had a rights-issue within the five-year period. Together they comprise $67 \%$ of the top quintile. From the 54 companies in the top quintile for a high non-cash working capital ratio, 39 have either been delisted, been part of a business combination or had a rights -issue within the five-year period or thereafter. That comprises $72 \%$ of the top quintile. It seems precarious for a company to be in either of the top quintiles, so much more if it qualifies for both top quintiles.

The companies that had fallen in both the upper quintiles of these ratios were identified (Table 3). From the ten companies that had qualified, only one, Oakfields Thoroughbreds, is still listed or had no rights-issues. The rest had all either been delisted, or had been part of a business combination or had to do a rights -issue and not always in the best of circumstances either. Oakfields Thoroughbreds probably would not have been an exception, if it had not been for the controlling shareholder. The auditors did not qualify their audit opinion in the 2000 financial report, however, they did draw attention to the note on going concern: 'the controlling shareholder has pledged its financial support to the Group ... The directors are confident that the Group will continue as a going concern in the year ahead.' At the end of 2000 the non-current liabilities were $159 \%$ of total shareholders' equity. More than half of that comprises unsecured, indefinite period, interest-free loans. Therefore, Oakfield Thoroughbreds can be grouped with the other nine companies, since its controlling shareholder is helping to keep the company afloat.

Even although seven of them had an above average net profit after taxation, the cash flow from operating activities had not been sufficient to ascertain that the companies could survive. In the case of four companies, the average cash flow from operating activities had been negative even before payment of any dividends, repayment of debt or acquiring any non-current assets associated with such a high expansion rate.

If a company manages its growth, non-cash working capital or net profit ratio, it may be possible to get itself out of the predicament it grew itself into. One company, Medhold, does not appear in the top quintiles over an average of four years, because it more than halved its average growth rate. Medhold's growth rate had been below average over the last two years of existence, but the average net loss did not help the cash flow position at all.

The conclusion thus reached was that if a company does grow extensively for an average of five years while carrying a large amount of non-cash working capital, the probability of not surviving on its own is significant. That brought the next question to mind: what will happen with companies in the top quintile over a shorter period, for instance four years (Table 4)? Three hunderd companies had been listed for at least four years within the period under review.

From the 60 companies in the top quintile for a high sales growth on an average for four years, 22 had either been delisted or been part of a business combination. From the 38 still listed, fourteen had a rights-issue within the four-year period or thereafter. That comprises $60 \%$ of the top quintile. From the 60 companies in the top quintile for a high noncash working capital ratio, 43 had either been delisted, been part of a business combination or had done a rights -issue within the four-year period or thereafter. That comprises $72 \%$ of the top quintile. Again, it seems dangerous for a company to be in either of the top quintiles.

From the fourteen companies that were both growing quickly and had a large amount of non-cash working capital, only two that are still listed did not have a rights-issue, namely Oakfield Thoroughbreds, which is surviving because of a controlling shareholder, and LA Retail Stores. LA Retail Stores has quite a high net profit margin and is successful in generating a healthy positive cash flow from operating activities.

Table 3: Companies in the top quintile of high growth as well as non-cash working capital on average for a five -year period

\begin{tabular}{l|c|c|c|c|l}
\hline \multicolumn{1}{c|}{ Company } & $\begin{array}{c}\text { Non-cash } \\
\text { working } \\
\text { capital to } \\
\text { sales \% }\end{array}$ & $\begin{array}{c}\text { Sales growth } \\
\%\end{array}$ & $\begin{array}{c}\text { Net profit } \\
\text { after taxation } \\
\text { to sales \% }\end{array}$ & $\begin{array}{c}\text { Cash flow from } \\
\text { operating } \\
\text { activities to sales } \\
\%\end{array}$ & Listed, Rights-issue, Business combination or delisted \\
\hline Consolidated Metallurgical & $39,24 \%$ & $34,31 \%$ & $13,50 \%$ & $10,04 \%$ & Delisted 17 August 1998 Scheme of arrangement with Sudelektra \\
Industries & $71,13 \%$ & $47,83 \%$ & $7,46 \%$ & $-13,04 \%$ & Listed Rights-issue 31 March 1999 \\
HomeChoice & $39,59 \%$ & $62,39 \%$ & $9,48 \%$ & $1,36 \%$ & Suspended 6 October 2000 Rights-issue 29 April 1999 \\
Leisurenet & $29,07 \%$ & $80,58 \%$ & $8,25 \%$ & $4,02 \%$ & Final liquidation granted on 9 November 1999 Rights-issues 20 May \\
Macmed Health Care & $29,67 \%$ & $53,52 \%$ & $-0,45 \%$ & $-2,57 \%$ & Reverse takeover by Aspen Healthcare Holdings \\
Medhold & $76,41 \%$ & $78,31 \%$ & $10,48 \%$ & $17,66 \%$ & Delisted February 2002 Rights-issue 19 March 1997 \\
Monex & $39,95 \%$ & $30,83 \%$ & $4,07 \%$ & $2,26 \%$ & Acquired by Profurn Rights-issue 22 August 1996 \\
Morkels Retail Group & $121,63 \%$ & $37,72 \%$ & $-189,31 \%$ & $-140,07 \%$ & Listed Controlling shareholder is keeping company afloat \\
Oakfields Thoroughbreds & $65,86 \%$ & $60,93 \%$ & $14,47 \%$ & $-5,02 \%$ & Listed Rights-issue announced 11 February 2002 after liquidation had \\
Profurn & $28,09 \%$ & $77,38 \%$ & $3,30 \%$ & $7,64 \%$ & been an option \\
& &
\end{tabular}


Table 4: Companies in the top quintile of high growth as well as non-cash working capital on average for a four-year period

\begin{tabular}{|c|c|c|c|c|c|}
\hline Company & $\begin{array}{c}\text { Non-cash } \\
\text { working } \\
\text { capital to } \\
\text { sales \% } \\
\end{array}$ & Sales growth & $\begin{array}{c}\text { Net profit } \\
\text { after } \\
\text { taxation to } \\
\text { sales \% }\end{array}$ & $\begin{array}{c}\text { Cash flow from } \\
\text { operating activities } \\
\text { to sales \% }\end{array}$ & Listed, Rights-issue, Business combination or delisted \\
\hline Alliance Pharmaceuticals & $28,24 \%$ & $38,02 \%$ & $4,32 \%$ & $2,08 \%$ & Listed Rights-issue 11 July 1996 \\
\hline Arthur Kaplan Jewellery Holdings & $46,68 \%$ & $33,37 \%$ & $7,25 \%$ & $0,17 \%$ & Delisted 14 November 1997 Rights-issue 27 June 1996 \\
\hline $\begin{array}{l}\text { Carson Holdings } \\
\text { Consolidated Metalluroical }\end{array}$ & $41,08 \%$ & $125,94 \%$ & $12,16 \%$ & $0,86 \%$ & Delisted 27 October 2000 Rights -issue 19 June 1997 \\
\hline $\begin{array}{l}\text { Consolidated Metallurgical } \\
\text { Industries }\end{array}$ & $38,47 \%$ & $39,39 \%$ & $16,41 \%$ & $11,05 \%$ & Delisted 17 August 1998 Scheme of arrangement with Sudelektra \\
\hline HomeChoice & $72,77 \%$ & $48,02 \%$ & $7,40 \%$ & $-13,25 \%$ & Listed Rights-issue 31 March 1999 \\
\hline LA Retail Stores & $31,30 \%$ & $174,02 \%$ & $13,29 \%$ & $7,27 \%$ & Listed \\
\hline Leisurenet & $39,94 \%$ & $56,37 \%$ & $9,43 \%$ & $0,92 \%$ & Suspended 6 October 2000 Rights-issue 29 April 1999 \\
\hline Macmed Health Care & $28,61 \%$ & $101,38 \%$ & $8,38 \%$ & $4,42 \%$ & $\begin{array}{l}\text { Final liquidation granted on } 9 \text { November } 1999 \text { Rights-issues } 20 \text { May } \\
1999,1 \text { August } 1996 \text { and } 9 \text { May } 1996\end{array}$ \\
\hline Monex & $72,16 \%$ & $68,27 \%$ & $11,62 \%$ & $18,69 \%$ & Delisted Feb 2002 Rights-issues 12 March 1998 and 19 March 1997 \\
\hline Morkels Retail Group & $38,69 \%$ & $41,33 \%$ & $4,21 \%$ & $1,16 \%$ & Acquired by Profurn Rights -issue 22 August 1996 \\
\hline Oakfields Thoroughbreds & $173,06 \%$ & $65,31 \%$ & $-195,82 \%$ & $-168,07 \%$ & Listed Controlling shareholder is keeping company afloat \\
\hline Profurn & $68,47 \%$ & $51,86 \%$ & $14,78 \%$ & $-5,06 \%$ & $\begin{array}{l}\text { Listed Rights -issue announced } 11 \text { February } 2002 \text { after liquidation had } \\
\text { been an option }\end{array}$ \\
\hline Silveroak Industries & $34,53 \%$ & $32,83 \%$ & $3,24 \%$ & $-3,61 \%$ & Delisted 16 January 1996 \\
\hline Strand Group Holdings & $30,12 \%$ & $115,81 \%$ & $3,14 \%$ & $6,52 \%$ & Delisted 27 November 2001 \\
\hline
\end{tabular}

\section{Conclusion}

Companies examined that were growing at a high rate and had a large amount of non-cash working capital provided evidence that such a company will most probably be liquidated, become part of a business combination or be forced to do a rights -issue if there is not a cash rich holding company somewhere in the background.

Rather than pursuing the ultimate growth rate, a company may be more successful in the long run, by growing at a more moderate tempo and rather ascertain that its cash flow is sufficient to provide for the day-to-day activities of the company. The cash flow from operating activities must be sufficient to carry the company without it being necessary to struggle in a search of willing partners to provide the necessary finance just for survival purposes.

\section{References}

Dechow, P.M. 1994. 'Accounting earnings and cash flows as measures of firm performance: The role of accounting accruals', Journal of Accounting \& Economics 18:3-42.

Financial statements of all the companies studied for the specific years.

Foster, B.P. \& Ward, T.J. 1997. 'Using cash flow trends to identify risks of bankruptcy’, CPA Journal, 67(9):60-61.

Hertenstein, J. \& McKinnon, S. 1997. 'Solving the puzzle of the cash flow statement', Business Horizons, 40(1):69-76.

http://www.moneymax.co.za/bfanet/co_r.../report.asp

Hull, J. 1990. 'Monitoring a company's operating cash flow using variance analysis', Accounting Horizons, 4(3):50-57.

Profile's Stock Exchange Handbook, 2000. Johannesburg: Profile Media.
Shroff, P.K. 1998. 'Properties of accrual income, cash flow and security return: An interpretive exercise', Issues in Accounting Education, 13(4):1019-1030.

South African Institute of Chartered Accountants. 1999. Statements of Generally Accepted Accounting Practice: AC 101: Presentation of financial statements, Reviewed February. Natal Witness Commercial Printers.

South African Institute of Chartered Accountants. 1996. Statements of Generally Accepted Accounting Practice: AC 118: Cash flow statements, Reviewed September. Kengray. Natal Witness Commercial Printers. 